\title{
Incorporating Reading in Writing Classes and Its Effects on ESL Learners' Writing
}

\author{
Lydia Emak ${ }^{1}$ Hanita Hanim Ismail ${ }^{2 *}$ \\ ${ }^{1}$ Sekolah Menengah Kebangsaan Selirik, Kapit, Malaysia \\ ${ }^{2}$ Faculty of Education, Universiti Kebangsaan Malaysia, Bangi, Malaysia \\ Email: ^hanitaismail@ukm.edu.my
}

How to cite this paper: Emak, L., \& Ismail, H. H. (2021). Incorporating Reading in Writing Classes and Its Effects on ESL Learners' Writing. Creative Education, 12, 1949-1962. https://doi.org/10.4236/ce.2021.128149

Received: July 21, 2021

Accepted: August 22, 2021

Published: August 25, 2021

Copyright $\odot 2021$ by author(s) and Scientific Research Publishing Inc. This work is licensed under the Creative Commons Attribution International License (CC BY 4.0).

http://creativecommons.org/licenses/by/4.0/

\begin{abstract}
This study investigated how incorporating reading activities in writing classes can help secondary school students develop their writing skills. The study was conducted using samples selected conveniently which involved 30 Form Four and Five students from one of the local secondary schools in Kapit, Sarawak. This study examined specifically on the effects of engaging reading activities in writing classes on their writing performance. This qualitative study examined how incorporating reading activities into writing classes can influence students' writing results. Data was collected from a semi-structured interview and a pre- and post-test experimental research based on writing tests that were graded using the Common European Framework Reference (CEFR) writing marking scheme. The result was analysed using descriptive statistic to find the mean and standard deviation of both pre and post-test. Findings showed that incorporating reading activities into writing tasks during English language class increased the respondents' writing output significantly. The results of this study are hoped to assist English as Second Language (ESL) students and teachers in recognising the importance of reading activities in writing classes as an effort to improve writing performance.
\end{abstract}

\section{Keywords}

ESL, Reading, Writing, Writing Performance, ESL Classroom

\section{Introduction}

English is stipulated as a second language in Malaysia, where its role and functions have been institutionalised in the Education Ordinance since 1957, and reinforced in the Education Act as well mandated in the National Education Policy 1970 (Azman, 2016). The announcement of the English Language Education Roadmap for Malaysia 2015-2025, which is an extension of the Malaysia 
Education Blueprint (MEB), is the fourth and most recently implemented reform (Don et al., 2015). In general, MEB aims to raise the nation's educational level to suit the global norms by aligning the system with the CEFR, which is an international standard in the hope to inculcate English proficiency among Malaysian citizens.

Since the early 1980s, the Ministry of Education (MoE) has employed a processbased approach to writing in school curricula and syllabi. Despite the implementation of a process-based approach to writing in Malaysian national curriculum and syllabus, students' writing performance in both, primary and secondary school examinations remains poor (Kwan \& Yunus, 2014). On average, Malaysian students perform poorly in English language exams, particularly in the writing area (Azman, 2016), which yields upon many reforms at many levels (Rashid et al., 2017). This is in line with the current job demands as highlighted by the MoE as an effort to expose Malaysians students with job skills in order to create human capital and keep the country globally competitive. One of the ways to posit functionality is through the emphasis of English writing skills in order to develop pupils towards becoming competent writers.

In general, a total of 200 minutes are given each week for Malaysian school teachers to teach the combined four English language skills where 80 minutes are specified for the teaching of writing, with the goal of teaching pupils how to use language for interpersonal, informative, and aesthetic objectives. Previously, upper-class students were taught two styles of writing: Guided and Continuous Writing. Continuous Writing is free-form writing on a specific topic, whereas Guided Writing entails generating structured writing. At present, there are three types of writing featured in the writing paper since the implementation of CEFR: Short Communicative Message, Guided Writing, and Extended Writing. Based on the Curriculum and Assessment Standard Documents (DSKP) for both Form Four and Five students, the Content Standards for writing emphasise on the ability to communicate meaning while using appropriate language, form, and style. In terms of Learning Standards, the two Content Standards are roughly evenly split, which emphasises the significance of writing fluency and precision. The following are the two content standards in the DSKP:

1) Communicate intelligibly through print and digital media on familiar topics.

2) Communicate with appropriate language, form and style.

Reading and writing are inextricably linked. By reading books that provide students with plenty of vocabulary and rhyming or repetitive patterns can help students to use their higher order thinking skills to develop their own story line (Wilson, 2016). Allowing students to recognise good writing techniques in their readings and providing opportunities for them to practise these techniques will help their transition to becoming better writers. Allowing students to read and explore simple stories with a beginning, middle, and end also will help them to incorporate these important components into their own narratives (Held, 2010). The benefits of teaching reading and writing together outweigh the benefits of 
teaching them separately. Therefore, the focus of this study is incorporating reading into writing classes and its effects on secondary school ESL learners' writing.

\subsection{Research Objectives}

The general objective of this study is to investigate the impact of incorporating reading activities in efforts to improve the writing performance. The specific objectives are as follows:

1) To assess the effect of reading activities on students' English writing performance.

2) To ascertain the relationship between reading and writing in enhancing students' writing performance.

\subsection{Research Questions}

In order to achieve the objectives, two research questions are formulated. They are:

1) How reading affect students' English writing performance positively?

2) Is there a relationship between students' reading and writing to promote better writing performance?

\section{Literature Review}

\subsection{Writing in Malaysia and Its Incorporation with Reading Skills}

There is a large body of literature on ESL in Malaysia focusing on pupils' lack of writing skills (e.g. Mukundan et al., 2013; Swanto \& Din, 2014; Ramadi, Ramadi, \& Nasr, 2016; Yunus et al., 2019). Despite the long exposure to English, many Malaysian students do not appear to be proficient in English, especially in writing skills.

While reading is a skill of understanding text meaning including comprehending the writer's writing style, the latter's vocabulary range, spelling and grammar (Krashen, 2014) which requires the readers to decode and make sense (Linse \& Nunan, 2005), writing is a deliberate social communication that also measures literacy (Tan \& Miller, 2008). Individuals with writing issues may struggle with one or more components of the writing process, including proper grammar, norms, punctuation, capitalization, spelling, and some of the basic parts of writing.

Efforts in improving writing skills have taken up different directions. While some suggest taking up digital technologies as a means to help lessen the strains of mastering writing (e.g. Suhaimi et al., 2019; Yunus et al., 2019), there is another direction which has long observed the potential of combining another language skill in order to improve writing. In fact, this branch of scholarship seems to be continuously researched on. Among its main arguments is the interconnection between the two skills (Moran \& Billen, 2014; Li, 2015; Li, 2016; Arum, 2018; Linuwih \& Winardi, 2020). In fact, better authors read more than 
poor writers since reading functions as an invaluable resource (Al Raqqad et al., 2019) and better readers write more syntactically developed language. For a long time, people have recognised the link between reading and writing. There are empirical evidences that emphasise the importance of a combined reading and writing strategy, which also claim that having expertise in one skill leads to development in the other (e.g. Lee, 2000; Ien et al., 2017). In fact, writers are encouraged to read more in response to the content they have read in order to gain more knowledge and to strengthen their critical thinking skills. Both, reading and writing are active and productive ways of discovering meaning. According to Harl (2013), reading is the process of extracting meaning from a text, whereas writing is the activity of making it. Regular reading improves writing skill, and the learners' writing skills will inevitably increase as a result of what they read. Writing has an impact on their thinking and boosts their higher-order thinking.

\subsection{Schema Theory}

According to schema theory, in order to construct context and achieve the maximum comprehension, a reader must communicate with the text material using their current schema. Similarly, a writer employs the same schemata that are used for reading comprehension. In order to write on a subject, a writer needs to have prior knowledge (schemata) about it. As a result, these schemata serve as instruments for writing. Because of our similar knowledge of schema in reading and writing, we feel that reading will enhance the writing process by providing schemata.

While Bartlett proposed the schema theory in 1932, names like Anderson and Stanovich further refined it as one of the prominent cognitivist learning theories in the 1970s and 1980s. Since schema theory defines how knowledge is received, processed, and cerebrally arranged. Humans have general knowledge in the form of unconscious mental structures (schemata), which induce schematized memory errors when these structures interact with incoming data. As a result, schemata affect new information based on prior knowledge. Schemata are mental representations for specific pieces of complex knowledge that are then stored in long-term memory, according to psychology. Schema theory emphasises the importance of general information in the formation of mental depictions. Teachers' responsibility in the educational process would be to aid students in the development of new schemata and the establishment of links between them, so improving their memory. Prior knowledge and background information are equally as essential. Schema theory can be utilised in a variety of situations, but it is most commonly employed to aid in the learning of a second language because it demands reading a large number of texts in the target language. Reading comprehension and, as a result, understanding another language will be challenging if we do not construct a sufficient number of schemata when reading a book.

The ability to grasp the words contained in a text and apply the knowledge to one's personal growth and development is known as reading (Dadzie, 2008). 
This entails deducing meaning from documented material in a person's life, whether printed or unprinted. People read for a variety of reasons and purposes, including pleasure, leisure, relaxation, information, and knowledge. Under the constructive orientation, reading and writing connections have been proposed. Readers and writers must both actively participate in interpreting and creating meaning from the texts. To put it another way, a reader must interpret the text and draw conclusions based on prior knowledge and experience. Similarly, a writer generates ideas from his or her own background experience to construct meaning.

Reading functions as a stimulus in these research, causing readers to experience and produce ideas in reaction to the materials they are reading. Personal responses and feelings are shared by readers, which can be communicated in expressive writing. As a result, reading is employed as a source of incentive to encourage writing. Other researchers have discovered that reading a lot can improve a student's overall writing ability. Krashen (1984), for example, discovers that good writers read more outside of class than poor writers. Besides discussing about the benefits of linking reading and writing, Plakans and Gebril (2012) also recommend steps to be followed. To begin, the reading materials provided assist students in forming thoughts about the subject. Following that, the reading materials used to form thoughts on the subject are used. Finally, the resources' texts can be used as evidence as well as language support. Durukan (2011) also emphasises the significance of incorporating reading into writing for students' language learning development. Reading, along with writing, was the first skill to be learned among the four language skills.

\subsection{Reading Practices}

Reading is a necessary skill for students of all ages. Shared reading is one of the reading practises that is known to improve reading fluency and print concepts and is being re-searched as an intervention to support narrative writing (Policastro, 2018). Shared reading is also defined as reading aloud to students a short and simple story while providing reading strategy support and opportunities to interact with the text (Hudson \& Test, 2011).

Another reading technique is "repeated reading," which can be done at school or at home. "Children's fluency increases considerably when they are given regular opportunity to read books aloud" (Alber-Morgan, 2006: p. 273). Regularly reading aloud to a child helps the child improve his or her fluency and reading coordination. Reading is an important literacy skill that affects a student's academic performance. ESL students are taught a variety of reading abilities, including skimming and scanning, making references and inferences, and critical thinking.

\section{Methodology}

This qualitative study gathered data using a pre- and post-test writing assess- 
ments and a semi-structured interview. While the pre-test writing assessment was administered during the respondents' regular writing class (where writing skill was taught separately), the post-test writing assessment took place during a reading-writing class. At the end of the study, an informal interview was conducted to better understand the students' reactions to the reading-to-writing activity.

Based on a convenient sampling technique, 30 participants were from one of Kapit secondary schools Form Four and Five classes. The participants were conveniently chosen since they are all familiar with the latest format of SPM Writing paper and they are all one of the researchers' students. The size of the sampling is comparatively acceptable since the minimum number of participants for a pilot study is ten (Saunders et al., 2019).

1) Pre-test writing assessment

Because the participants were conveniently chosen among the upper form students, the researchers conducted the pre-test writing assessment in relation to health issues. The participants were informed that their writing assessment for the day would be part three of their writing paper, SPM1119/2: Extended Writing where they were asked to write an essay on the given issue.

2) Post-test writing assessment

The post-test writing assessment consisted of two parts-a) a 20-minute reading activity and $b$ ) the post-test writing assessment itself. This allowed the investigation on the contribution of reading on improving writing performance.

A reading material is an article by Oaklander and Jones's entitled " 7 Surprising Benefits of Exercise" was specifically chosen to suit the theme of the week, which was "Health and Environment". The reading activity, which is named as the "Plus-Minus-Interesting" activity (as indicated in Table 1) teaches the participants how to evaluate and form opinions about what they read. Based on the given reading material, the participants were asked to find important information and fill in any of the three columns of "Plus-Minus-Interesting". The Plus column could entail writing ideas that they identified to be as either positive or what they liked, the Minus column consisting ideas that are negative or that they do not like and the Interesting column include ideas that they find as interesting.

Upon reading, the participants were asked to write a four-paragraph essay as a follow-up to this activity, including one paragraph based on their "Plus-MinusInteresting" activity as a post-test for the study. They were asked to comment about Oaklander and Jones' article. They were instructed to write based on their findings as recorded in their Plus-Minus-Interesting columns for the body of their essay, and the last paragraph was their conclusion paragraph.

Both writing assessments were then marked using the CEFR writing marking scheme where the essays were graded based on four descriptors: content, communicative achievement, organisation, and language (Table 2).

3) Interview Protocol

Participants were formally interviewed at the end of the study to learn more 
Table 1. "Plus-minus-interesting" chart.

\begin{tabular}{ccc}
\hline \multicolumn{4}{c}{ "7 Surprising Benefits of Exercise" by Oaklander and Jones } \\
\hline PLUS & MINUS & INTERESTING \\
\hline $\mathrm{xx}$ & $\mathrm{xx}$ & $\mathrm{xx}$ \\
\hline
\end{tabular}

Table 2. CEFR Writing assessment subscales.

\begin{tabular}{|c|c|c|c|c|}
\hline B2 & CONTENT & $\begin{array}{l}\text { COMMUNICATIVE } \\
\text { ACHIEVEMENT }\end{array}$ & ORGANISATION & LANGUAGE \\
\hline 5 & $\begin{array}{l}\text { All content is relevant to the } \\
\text { task. Target reader is fully } \\
\text { informed. }\end{array}$ & $\begin{array}{l}\text { Uses the conventions of the } \\
\text { communicative task effectively to } \\
\text { hold the target reader's attention } \\
\text { and communicate straightforward } \\
\text { and complex ideas, as appropriate }\end{array}$ & $\begin{array}{l}\text { Text is well organised and } \\
\text { coherent, using a variety of } \\
\text { cohesive devices and } \\
\text { organisational patterns to } \\
\text { generally good effect. }\end{array}$ & $\begin{array}{l}\text { Uses a range of vocabulary, including } \\
\text { less common lexis, appropriately. Uses } \\
\text { a range of simple and complex } \\
\text { grammatical forms with control and } \\
\text { flexibility. Occasional errors may be } \\
\text { present but do not impede } \\
\text { communication. }\end{array}$ \\
\hline
\end{tabular}

4 Performance shares features of Bands 3 and 5
Minor irrelevances and/or
3 omissions may be present.
3 Target reader is on the whole informed.
Uses the conventions of the communicative task to hold the target reader's attention and communicate straightforward ideas.
Text is generally well organised and coherent, using a variety of linking words and cohesive devices.
Uses a range of everyday vocabulary appropriately, with occasional inappropriate use of less common lexis. Uses a range of simple and some complex grammatical forms with a good degree of control. Errors do not impede communication.

Uses everyday vocabulary generally Text is connected and coherent, appropriately, while occasionally using basic linking words and a overusing certain lexis. Uses simple limited number of cohesive devices. grammatical forms with a good degree of control. While errors are noticeable, meaning can still be determined. misinterpretation of task may be present. Target reader is minimally informed. straightforward ideas.

\section{Uses the conventions of the}

about their reactions and feedback to the reading-to-writing activity. These interviews are basically conversations between the interviewer and the interviewee that is conducted for a specific purpose (Turner III, 2010). This instrument allowed the researchers to gain access to the participants' unseen perceptions, feelings, and opinions. To qualitatively analyse the participants' attitudes toward the integration of reading activities in writing class, this study used semi-structured interview questions which were adapted from Al-Ghonaim's (2005) study.

To explore the participants' perspectives on the integration of reading-writing, this study relied entirely on an open-ended semi-structured interview. The researchers only extracted the most important questions. Some questions were excluded because they were deemed extraneous to the topic at hand. The participants in this study were encouraged to speak freely because the interviewer would learn more if they did (Lincoln \& Guba, 1985). The interview lasted 20 minutes and was written down. Finally, the interview responses were analysed 
using Braun and Clarke's (2006) six phases of theme analysis.

In the 1970s, Holton established thematic analysis, which is currently recognised as a "differentiated method in social research with a fully described set of processes" (Braun \& Clarke, 2013: p. 178). Thematic analysis is a data analysis technique that assists any researcher in identifying themes and patterns of meaning across a dataset in relation to specific research questions. This method may be used to large or small datasets and can be used to examine virtually any sort of qualitative data, including interviews, focus groups, and qualitative surveys.

Table 3 explains Braun and Clarke's set of procedures at administering a thematic analysis. In order to observe things of interest, the researchers must be well familiar with the data (Step 1) before stating the coding and recognising themes. After the researchers were comfortable with the data, they began building early codes (Step 2) or "terms or brief phrases that express the essence of why you think a certain bit of data may be useful" (Braun \& Clarke, 2013: p. 207). To answer the research questions, coding entailed finding all relevant pieces of data within the full dataset. After all the coding in the dataset was identified, patterns were located. The frequency of appearance of a certain code is significant in order to determine useful patterns for answering a specific research topic.

The next stage was to find the data's larger patterns that can be used to answer the research questions or known as theme (Step 3). A theme is a "central organising notion" (Braun \& Clarke, 2013: p. 224), which is a set of codes that can be used to capture a collection of ideas or aspects. Finally, an analysis was developed where the themes were reviewed (Step 4), defined (Step 5) and written up (Step 6). Each topic as well as associated data obtained via codes, was presented in order to tell the story of the data in relation to the research questions. The identified themes were to be presented in light of preceding literature on the empirical topic in question, which in this case is "How can reading improve students' English writing performance?" and "Is there a relationship between students' reading and writing to promote better writing performance?”.

\section{Analysis and Discussion}

The findings will be discussed according to the research questions.

Table 3. Braun and Clarke's (2006) six phases of thematic analysis.

\begin{tabular}{cc}
\hline STEPS & PHASE \\
\hline 1 & Familiarization \\
2 & Developing initial codes \\
3 & Searching for themes \\
4 & Thematic review \\
5 & Thematic definition \\
6 & Write-up \\
\hline
\end{tabular}




\subsection{Positive Impact of Reading on Writing Performance}

Table 4 lists down the results of the administered pre- and post-tests for writing assessments in order to investigate the impact of incorporating reading activities in writing class that helps improve writing performance among the research participants. The scores for both pre- and post-test writing assessments are based on similar criteria used for CEFR, including task completion, language accuracy,

Table 4. Pre- and post-test of writing assessments marks.

\begin{tabular}{|c|c|c|}
\hline Participants & Pre-test $(20 \%)$ & Post-test (20\%) \\
\hline Participant 1 & 6 & 13 \\
\hline Participant 2 & 11 & 15 \\
\hline Participant 3 & 9 & 13 \\
\hline Participant 4 & 7 & 13 \\
\hline Participant 5 & 6 & 12 \\
\hline Participant 6 & 7 & 15 \\
\hline Participant 7 & 8 & 14 \\
\hline Participant 8 & 11 & 16 \\
\hline Participant 9 & 12 & 16 \\
\hline Participant 10 & 16 & 18 \\
\hline Participant 11 & 6 & 17 \\
\hline Participant 12 & 8 & 17 \\
\hline Participant 13 & 8 & 15 \\
\hline Participant 14 & 6 & 13 \\
\hline Participant 15 & 7 & 15 \\
\hline Participant 16 & 9 & 17 \\
\hline Participant 17 & 9 & 15 \\
\hline Participant 18 & 10 & 17 \\
\hline Participant 19 & 13 & 18 \\
\hline Participant 20 & 13 & 18 \\
\hline Participant 21 & 13 & 17 \\
\hline Participant 22 & 15 & 17 \\
\hline Participant 23 & 16 & 18 \\
\hline Participant 24 & 7 & 16 \\
\hline Participant 25 & 15 & 18 \\
\hline Participant 26 & 11 & 17 \\
\hline Participant 27 & 14 & 18 \\
\hline Participant 28 & 13 & 17 \\
\hline Participant 29 & 15 & 19 \\
\hline Participant 30 & 12 & 19 \\
\hline
\end{tabular}


organisation and development, and sentence structure. The marks were assigned based on the four marking descriptors-content, communicative achievement, organisation, and language, with $5 \%$ allocated to each. According to the findings, majority of the participants lacked confidence in their ability to complete the assigned task. They had doubts about their ability to write more than ten sentences or one paragraph. Because most students in Kapit are Dayaks and the common language used is Iban, such difficulty appears inevitable for the participants when they were asked to write in a different language.

The participants also indicated a limited range of vocabulary and sentence structures in their writing. When asked to produce an English piece, all of them recognised that writing with low language skills and expressing oneself clearly with the "blank" mind would be tough. Table 4 shows that 13 of the participants scored less than 10\%, and there were quite a few of them; 5 of them, in particular, demonstrated quite impressive writing quality during the pre-test assessment, scoring more than $15 \%$ out of a possible $20 \%$.

The findings in Table 4 showed a significant improvement in the participants' written production in their post-test writing assessment after incorporating the reading activity. In the post-test writing assessment, 24 of the participants scored more than $15 \%$, which equates to $80 \%$, compared to the pre-test writing assessment, where only 5 of 30 participants could score more than $15 \%$ in their writing. The amount of reading they did, as well as their ability to apply what they read to their writing, resulted in the improvements of their understanding and use of proper English. Based on their writings, some of them used and maintained the use of the original words from Oaklander and Jones's article in their writings. The participants also corrected their erroneous punctuations which were weakly used in their pre-test writing assessment. The participants' ability to forge a link between their reading and the application of knowledge onto writing evidently shows the use of schemata and indirectly shows that better writers read more (Krashen, 1984; Plakans \& Gebril, 2012).

\subsection{Relationship between Reading and Writing in Promotion of Better Writing Performance}

The data of both the pre- and post-tests was then analysed using descriptive statistics, yielding the results as presented in Table 5. Table 5 shows that the post-test results $(\mathrm{M}=16.1, \mathrm{SD}=2.0)$ were significantly higher than the Pre-test results $(\mathrm{M}=10.43, \mathrm{SD}=3.32)$. The participants' considerable improvement in writing performance in the post-test demonstrated that incorporating reading activities into writing lessons did play a key role in boosting writing achievement for ESL students.

Table 5. Descriptive statistics for pre and post-test scores.

\begin{tabular}{cccc}
\hline & N & Mean & SD \\
\hline Pre-test & 30 & 10.43 & 3.32 \\
Post-test & 30 & 16.1 & 2.0 \\
\hline
\end{tabular}


Table 6. Themes from the coded data.

\begin{tabular}{ll}
\hline \multicolumn{1}{c}{ Codes } & \multicolumn{1}{c}{ Themes } \\
\hline - Able to write longer sentences. & \\
- Use some information in the article read in writing. & 1) Initiating ideas for writing \\
- Use the vocabulary and sentence pattern. & \\
\begin{tabular}{ll} 
- Prefer the integration of reading in writing class. & 2) Students' outlooks on writing after \\
- Activated schemata makes writing easier & activity: \\
- Confidence in writing essays & a) more reflective \\
& b) positive \\
\hline
\end{tabular}
\end{tabular}

At the conclusion of the study, the participants were interviewed to obtain information on their opinions toward writing, reading, and the effectiveness of connecting reading and writing. According to the interview, prior to incorporating reading activities in writing class, all of the participants in their English class found writing to be a difficult and frustrating activity.

Using Braun and Clarke's thematic analysis, the researchers identified two primary themes which emerged from the interview (Table 6).

When asked what value they got from reading the article before writing an essay related to the same topic, all the participants agreed that the reading activity served as a resource for what they needed to write, reiterating claims by both Plakans and Gebril (2012) and Al Raqqad et al. (2019). These participants also concurred that the reading-to-writing activity was relevant to them since they were able to come up with something in order to write. It was also beneficial to them since they were able to make connections between the ideas and concepts presented in what they read. When asked if they had gained any knowledge from the article, the students stated that they had grown more reflective of their views and more confident in their writing abilities.

Participants reported that their writing had significantly improved after the intervention of having reading activities in writing class. They have claimed that they can recognise and acknowledge the common errors during the writing process. They had written "better" as a result of the intervention. Furthermore, they believed that reading had a positive impact on writing. Most participants reported that some useful words, phrases and grammatical structures of the paper given during the intervention were used to write their essays using the information gathered using the Plus-Minus-Interesting reading activity based on Oaklander and Jones's article. These feedbacks reiterate arguments in past studies (e.g. Moran \& Billen, 2014; Li, 2015; Li, 2016; Arum, 2018; Linuwih \& Winardi, 2020) that reading and writing are interconnected.

\section{Conclusion}

This research on incorporating reading activities in a writing classroom was able to show that not only the participants recognised the importance of reading but also concurred that the integration of reading activities in their writing class ac- 
tivated their schemata and helped better express themselves. The findings also indicated that the majority of the participants agreed that incorporating reading activities into their writing class has a significant impact on their writing performance and that there is a direct relationship between reading and writing in improving writing performance.

According to the study's findings, it is recommended that reading programmes such as D.E.A.R (Drop Everything and Read) in the Highly Immersive Programme (HIP) under the English Language Panel in school or Nilam Programme in school be made mandatory for all school students and closely monitored, particularly by their language teachers, i.e. Malay language teachers, Iban language teachers, and English language teachers, as this will go a long way toward incentivizing students to read. As how the positive result shown in this study about incorporating reading in writing classes can help ESL learners to write better, other teachers in Kapit also can apply the same approach in teaching writing which is by incorporating reading into writing classes. Finally, parents should also help their children develop reading skills when young so that they become a natural part of their future lives. Nowadays, many community libraries encourage children to read novels and fictions. They will be able to express themselves and write better English as a result of this, which will lead to improved academic performance in the near future.

Reading influences writing, and writing influences reading. Students who read frequently will improve their writing abilities. By reading a number of genres, students may acquire text structures and language, later apply to their own writing. Reading also provides young people with prior knowledge of their writing. We've read for a number of reasons, including learning. A large part of what we know comes from the literature we read, especially in school.

The length of time it took to teach the Reading-to-Writing intervention to the participants was one of the study's limitations. In this study, the intervention was taught for two weeks before the post-test writing assessment. It can, however, be extended to a year, for example, to achieve more valid results. Another limitation of this study is that, while there are numerous ways to improve students' writing ability, this study focused solely on one aspect which is to integrate reading activities and writing class to develop students' language skills as the best technique for effectively teaching or learning writing.

\section{Conflicts of Interest}

The authors declare no conflicts of interest regarding the publication of this paper.

\section{References}

Al Raqqad, Y. M., Ismail, H. H., \& Al Raqqad, K. M. (2019). The Impact of Reading Strategies on EFL Students: A Research Review. International Journal of English, Literature and Social Sciences, 4, 2042-2048. https://doi.org/10.22161/ijels.46.65

Alber-Morgan, S. (2006). Ten Ways to Enhance the Effectiveness of Repeated Readings. 
Journal of Early and Intensive Behaviour Intervention, 3, 273-279.

https://doi.org/10.1037/h0100341

Al-Ghonaim, A. S. (2005). ESL College Students' Beliefs and Attitudes about Reading-to-Write in an Introductory Composition Course: A Qualitative Study. Unpublished Doctoral Dissertation, Indiana University of Pennsylvania.

Arum, D. A. S. (2018). The Effect of Reading Habit on Students' Writing Performance. RETAIN, 6, 11-18.

Azman, H. (2016). Implementation and Challenges of English Language Education Reform in Malaysian Primary Schools. 3L: The Southeast Asian Journal of English Language Studies, 22, 65-78. https://doi.org/10.17576/3L-2016-2203-05

Braun, V., \& Clarke, V. (2006). Using Thematic Analysis in Psychology. Qualitative Research in Psychology, 3, 77-101. https://doi.org/10.1191/1478088706qp063oa

Braun, V., \& Clarke, V. (2013). Successful Qualitative Research: A Practical Guide for Beginners. SAGE Publications, Teachers College Press.

Dadzie, P. S. (2008). Reading for Education: The roles of Libraries. Ghana Library Journal, 20, 1-14. https://doi.org/10.4314/glj.v20i1.33978

Don, Z. M., Abdullah, M. H., Abdullah, A. C., Lee, B. H., Kaur, K., Pillai, J., \& Hooi, M. Y. (2015). English Language Education Reform in Malaysia: The Roadmap 2015-2025. Ministry of Education. https://anyflip.com/detl/zspi/basic

Durukan, E. (2011). Effects of Cooperative Integrated Reading and Composition (CIRC) Technique on Reading-Writing Skills. Educational Research and Reviews, 6, 102-109.

Harl, A. (2013). A Historical and Theoretical Review of the Literature: Reading and Writing Connections. In: A. Horning, \& E. Kraemer (Eds.), Reconnecting Reading and Writing (pp. 26-54). Parlor Press LLC and the WAC Clearinghouse.

Held, S. (2010). Dumping Graphic Organizers for a More Effective Approach to Prewriting Instruction. Illinois Reading Council Journal, 38, 20-28.

Hudson, M. E., \& Test, D. W. (2011). Evaluating the Evidence Base of Shared Story Reading to Promote Literacy for Students with Extensive Support Needs. Research \& Practice for Persons with Severe Disabilities, 36, 34-45. https://doi.org/10.2511\%2Frpsd.36.1-2.34

Ien, L., Yunus, M., \& Embi, M. (2017). Build Me Up: Overcoming Writing Problems among Pupils in A Rural Primary School in Belaga, Sarawak, Malaysia. Jurnal Pendidikan Humaniora, 5, 1-7. http://journal.um.ac.id/index.php/jph https://doi.org/10.17977/um030v5i12017p001

Krashen, S. (1984). Writing: Research, Theory and Applications. Language Arts, 60, 568-580.

Krashen, S. (2014). The Power of Reading. Libraries Unlimited.

Kwan, L. S. L., \& Yunus, M. M. (2014). Cohesive Errors in Writing among ESL Pre-Service Teachers. English Language Teaching, 7, 130-150. https://doi.org/10.5539/elt.v7n11p130

Lee, I. (2000). A Touch of Class! Exploring Reading-Writing Connections through a Pedagogical Focus on "Coherence". Canadian Modem Language Review, 57, 352-356. https://doi.org/10.3138/cmlr.57.2.252

Li, Z. (2015). Connecting Reading and Writing: A Case Study. English Language Teaching, 8, 150-158. https://doi.org/10.5539/elt.v8n6p150

Li, Z. (2016). A Case Study of Two College Students' Reading Strategies and Their Writing Styles. Journal of Arts and Humanities, 5, 15-23. 
https://doi.org/10.18533/journal.v5i7.972

Lincoln, Y., \& Guba, E. G. (1985). Naturalistic Inquiry. SAGE Publications.

Linse, C., \& Nunan, D. (2005). Practical English Language Teaching. McGraw-Hill.

Linuwih, E. R., \& Winardi, Y. K. (2020). The Influence of Reading Habit on Students' Writing Skill. Anglo-Saxon: Journal of the English Language Education Study Program, 11, 37-47. https://doi.org/10.33373/as.v11i1.2432

Moran, R., \& Billen, M. (2014). The Reading and Writing Connection: Merging Two Reciprocal Content Areas. Georgia Educational Researcher, 11, Article No. 8. https://doi.org/10.20429/ger.2014.110108

Mukundan, J., Mahvelati, E. H., Din, M. A., \& Nimehchisalem, V. (2013). Malaysian Secondary School Students' ESL Writing Performance in an Intensive English Program. World Applied Sciences Journal, 22, 1677-1684.

Plakans, L., \& Gebril, A. (2012). A Close Investigation into Source Use in Integrated Second Language Writing Tasks. Assessing Writing, 17, 18-34.

Policastro, M. M. (2018). Creating Collaborative Balanced Literacy Schools: A Framework for Implementation. Illinois Reading Council, 46, 16-24.

Ramadi, E., Ramadi, S., \& Nasr, K. (2016). Engineering Graduates' Skill Sets in the MENA Region: A Gap Analysis of Industry Expectations and Satisfaction. European Journal of Engineering Education, 41, 34-52. https://doi.org/10.1080/03043797.2015.1012707

Rashid, R. A., Rahman, S. B. A., \& Yunus, K. (2017). Reforms in the Policy of English Language Teaching in Malaysia. Policy Futures in Education, 15, 100-112. https://doi.org/10.1177\%2F1478210316679069

Saunders, M., Lewis, P., \& Thornhill, A. (2019). Research Methods for Business Students (4th ed.). Prentice Hall.

Suhaimi, N. D., Mohamad, M., \& Yamat, H. (2019). The Effects of Whatsapp in Teaching Narrative Writing: A Case Study. Humanities \& Social Sciences Reviews, 7, 590-602. https://doi.org/10.18510/hssr.2019.7479

Swanto, S., \& Din, W. A. (2014). Employing Drilling Technique in Teaching English Writing Skills to a Group of Rural Malaysian Students. Developing Country Studies, 4, 73-83.

Tan, E. K., \& Miller, J. (2008). Writing in English in Malaysian High Schools: The Discourse of Examinations. Routledge.

Turner III, D. W. (2010). Qualitative Interview Design: A Practical Guide for Novice Investigators. The Qualitative Report, 15, 754-760.

Wilson, L. (2016). Anderson and Krathwohl Bloom's Taxonomy Revised Understanding the New Version of Bloom's Taxonomy.

https://quincycollege.edu/wp-content/uploads/Anderson-and-Krathwohl_Revised-Blo oms-Taxonomy.pdf

Yunus, M. M., Zakaria, S., \& Suliman, A. (2019). The Potential Use of Social Media on Malaysian Primary Students to Improve Writing. International Journal of Education and Practice, 7, 450-458. https://doi.org/10.18488/journal.61.2019.74.450.458 